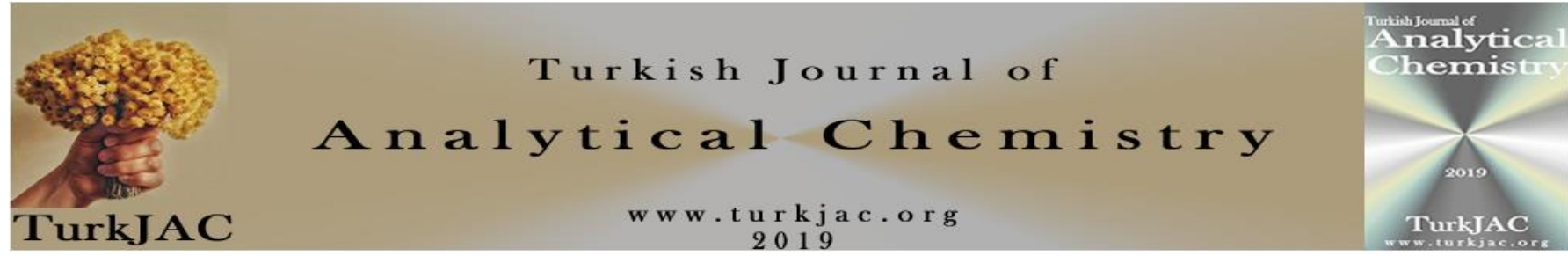

\title{
Chemometric approach based on factorial and Box-Behnken designs for determination of anti-coronavirus drug; favipiravir in bulk and spiked human plasma by green HPLC method
}

\author{
Safa M. Megahed ${ }^{1 *}$ (D), Ahmed A. Habib ${ }^{1}$ iD , Sherin F. Hammad ${ }^{1}$ iD , Amira H. Kamal ${ }^{1}$ iD \\ ${ }^{1}$ Tanta University, Faculty of Pharmacy, Department of Pharmaceutical Analytical Chemistry, 31111, Tanta, Egypt
}

\begin{abstract}
The present work describes the development of a robust, sensitive, and green HPLC method with fluorescence detection for the determination of favipiravir (FAV). A fractional factorial design was implemented for the screening of different factors affecting chromatographic responses. The Box-Behnken design was applied to study and optimize the most critical method parameters. The optimum chromatographic conditions obtained involved the use of $0.1 \%$ phosphoric acid solution and isopropanol in the ratio $98: 2 \% \mathrm{v} / \mathrm{v}$ as mobile phase at a flow rate of $0.8 \mathrm{~mL} / \mathrm{min}$ and column oven temperature of $35^{\circ} \mathrm{C}$. Chromatographic analysis was performed on Eclipse plus ${ }^{\circledR} \mathrm{C} 18(100 \mathrm{~mm} \times 4.6 \mathrm{~mm} \times 3.5 \mu \mathrm{m})$ column with fluorescence detector set at $361 \mathrm{~nm}$ and $432 \mathrm{~nm}$ for excitation and emission, respectively. A linear response was obtained over the range of $20-240 \mathrm{ng} / \mathrm{mL}$ with a limit of detection of $2.01 \mathrm{ng} / \mathrm{mL}$ and a quantitation limit of $6.11 \mathrm{ng} / \mathrm{mL}$. The method was successfully implemented for the determination of FAV in its pharmaceutical formulation with a mean \% recovery \pm SD of $99.42 \pm 0.59$. Moreover, the sensitivity of the method allowed the determination of FAV in spiked human plasma over a range of $40-240 \mathrm{ng} / \mathrm{mL}$. The combined application of green chemistry and quality by design leads to the development of a robust green method.
\end{abstract}

Keywords: Favipiravir, COVID-19 virus, Box-Behnken design, green chemistry, human plasma

\section{Introduction}

In December 2019, the first cases infected with the COVID-19 virus have emerged in Wuhan, China. Now, this virus becomes a pandemic all over the world. As of May 20, 2021, 33142485 cases have been diagnosed worldwide, and 444535 have died from the pandemic. COVID-2019 virus (also known as SARS-Cov-2) is a beta coronavirus which is enveloped positive strand RNA virus [1]. Unfortunately, no specific therapeutic agent has been approved for the treatment of the COVID-2019 virus till now. However, a number of already existing antiviral drugs which have been proved to be safe and effective against other viruses are tested for their activity against the COVID-19 virus. RNA-dependent RNA polymerase (RdRp) inhibitors are important. Favipiravir (FAV) which is known as T-705 is one of these drugs. Its chemical name is 6-fluoro-3-oxo-3,4- dihydropyrazine 2-carboxamide as shown in Fig. 1.

The Fujifilm Toyama Chemical Company has developed Favipiravir (Trade name: Avigan $\left.{ }^{\circledR}\right)$ in Japan. It selectively inhibits RNA-dependent RNA polymerase

Citation: S.M. Megahed, A.A. Habib, S.F. Hammad, A.H. Kamal, Chemometric approach based on factorial and Box-Behnken designs for determination of anti-coronavirus drug; favipiravir in bulk and spiked human plasma by green HPLC method, Turk J Anal Chem, 3(2), 2021, 70-78.

https://doi.org/ 10.51435/turkjac.963652
(RdRP), an enzyme required for RNA viral replication inside human cells [2]. In 2020, after the COVID-19 pandemic has spread, different studies were carried out to evaluate the efficiency of FAV against coronavirus [3$6]$.

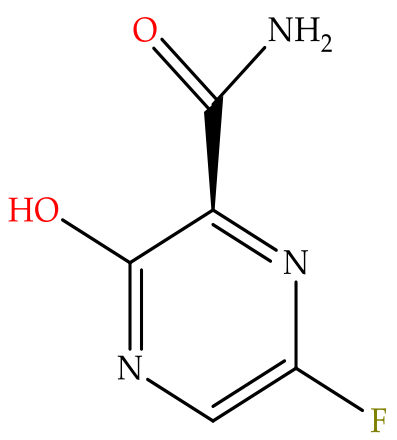

Figure 1. Chemical structure of favipiravir (FAV)

Literature review reveals that the reported methods for the analysis of FAV are HPLC with UV detection $[7,8]$. They involve the use of acetonitrile and phosphate solution as mobile phase. The spectrofluorimetric

*Author of correspondence: safa.megahed@gmail.com,

safa.megahed@pharm.tanta.edu.eg

Tel: +2 0403336409

Fax +2 0403336007

Received: July 10, 2021

Accepted: December 29, 2021 
method has been developed [9]. No chromatographic method with fluorimetric detection has been developed for quantitation of FAV neither in pure form nor in pharmaceutical preparation.

Recently, there is increasing interest in the development of green analytical methods that replace the highly toxic solvents with more eco-friendly ones and reduce the number of organic solvents used. Different tools have been proposed for the assessment of analytical procedures greenness. Among those tools, two quantitative tools are available including analytical eco-scale, and HPLC-EAT (environmental assessment tool). Analytical eco-scale assesses greenness based on penalty points given for each reagent amount and type, the energy consumed by the electrical instruments, and the way of waste treatment [10]. HPLC-EAT developed by Gaber et al is a specific tool used for the assessment of chromatographic methods regarding mobile phase solvents [11].

Implementation of Quality by Design (QbD) principles in different pharmaceutical fields is gaining interest nowadays. The application of $\mathrm{QbD}$ principles to analytical method development focuses on the concept of building quality into the method during development, instead of testing methods for quality after development. Application of the $\mathrm{QbD}$ approach ensures a robust method by following a systemic and organized path in method development.

Some experimental designs have been employed for the development, optimization, and validation of various analytical techniques [12-17]. Box Behnken Design (BBD) is one of them that are employed to obtain optimum conditions by examining the factors at three levels with a fewer number of experimental runs compared to other three-level designs such as three-level factorial design and Central Composite Design (CCD)[18].

The aim of the current work was to develop a green, simple, rapid, and robust HPLC method for the quantitation of FAV in pure form, pharmaceutical formulation, and spiked human plasma. The current study involves the implementation of $\mathrm{QbD}$ principles for the development of a green chromatographic method for the quantitation of FAV. The green character is built in the method development from the first step by taking analytical eco-scale and EAT scores as Critical Quality Attributes (CQAs) during screening and optimization phases. The developed method is the first chromatographic method for the determination of FAV in plasma. It was compared to the reported one and found to be greener, faster, and more sensitive [7].

\section{Experimental}

\subsection{Apparatus and software}

Chromatographic separation was made using of Agilent Technologies 1260 Infinity instrument (Santa Clara, USA) equipped with a G1311C quaternary pump, G1329B autosampler, G13b16A thermostatic column compartment, G1314F UV variable wavelength detector (VWD) detector, and G1321C fluorescence detector (FLD). This instrument was linked to a Dell-compatible PC, bundled with Agilent OpenLAB CDS Chemstation Edition software. $\mathrm{pH}$ measurements were carried out by using HANNA pH 211 Microprocessor $\mathrm{pH}$ meter with a double junction glass electrode. Design Expert ${ }^{\circledR}$ (Version 11.1.2.0, Stat-Ease Inc. Minneapolis, MN, USA) software was employed to form and analyze both fractional factorial and Box Behnken designs.

\subsection{Material and reagents}

Analytical grade chemicals and reagents were used throughout the study. Favipiravir (FAV) powder (percent assay 100.1\%) was obtained from Biophore India Pharmaceuticals Private Limited (Telangana, India). Analytical grade orthophosphoric acid purchased from Ridel-de Haën (Germany) was used. HPLC grade solvents as ethanol (Fisher Scientific, Germany), and isopropanol (Hipersolv, BDH Laboratory supplies, England) were used. All excipients used in the preparation of tablets were kindly supplied by the Pharmaceutical Technology Department, Faculty of Pharmacy, Tanta University (Tanta, Egypt). Human plasma was graciously provided by Tanta Blood BankTanta international educational hospital (Tanta, Egypt). The study was approved by the Research Ethics Committee at Faculty of Pharmacy, Tanta University, Egypt (Protocol code: TP/RE/6-19PH-003).

\subsection{Chromatographic conditions}

Separation and quantitation were carried out on Eclipse plus ${ }^{\circledR} \mathrm{C} 18(100 \mathrm{~mm} \times 4.6 \mathrm{~mm} \times 3.5 \mu \mathrm{m})$ column using a mixture of water containing $0.1 \%$ phosphoric acid solution and isopropanol in a ratio of $98: 2 \mathrm{v} / \mathrm{v}$ as mobile phase at a flow rate of $0.8 \mathrm{~mL} / \mathrm{min}$. The mobile phase was filtered through a $0.22 \mu \mathrm{m}$ nylon membrane filter (Millipore, Ireland) before use. The column temperature was set at $35^{\circ} \mathrm{C}$. The injection volume was $20 \mu \mathrm{L}$. The fluorescence detector was set at $361 \mathrm{~nm}$ and $432 \mathrm{~nm}$ for excitation and emission, respectively.

\subsection{Standard solution}

The stock solution of FAV was made in distilled water at a concentration of $400 \mu \mathrm{g} / \mathrm{mL}$ by dissolving an accurately weighed $10 \mathrm{mg}$ of FAV in a calibrated $25-\mathrm{mL}$ volumetric flask and completing the volume with water. The stock 

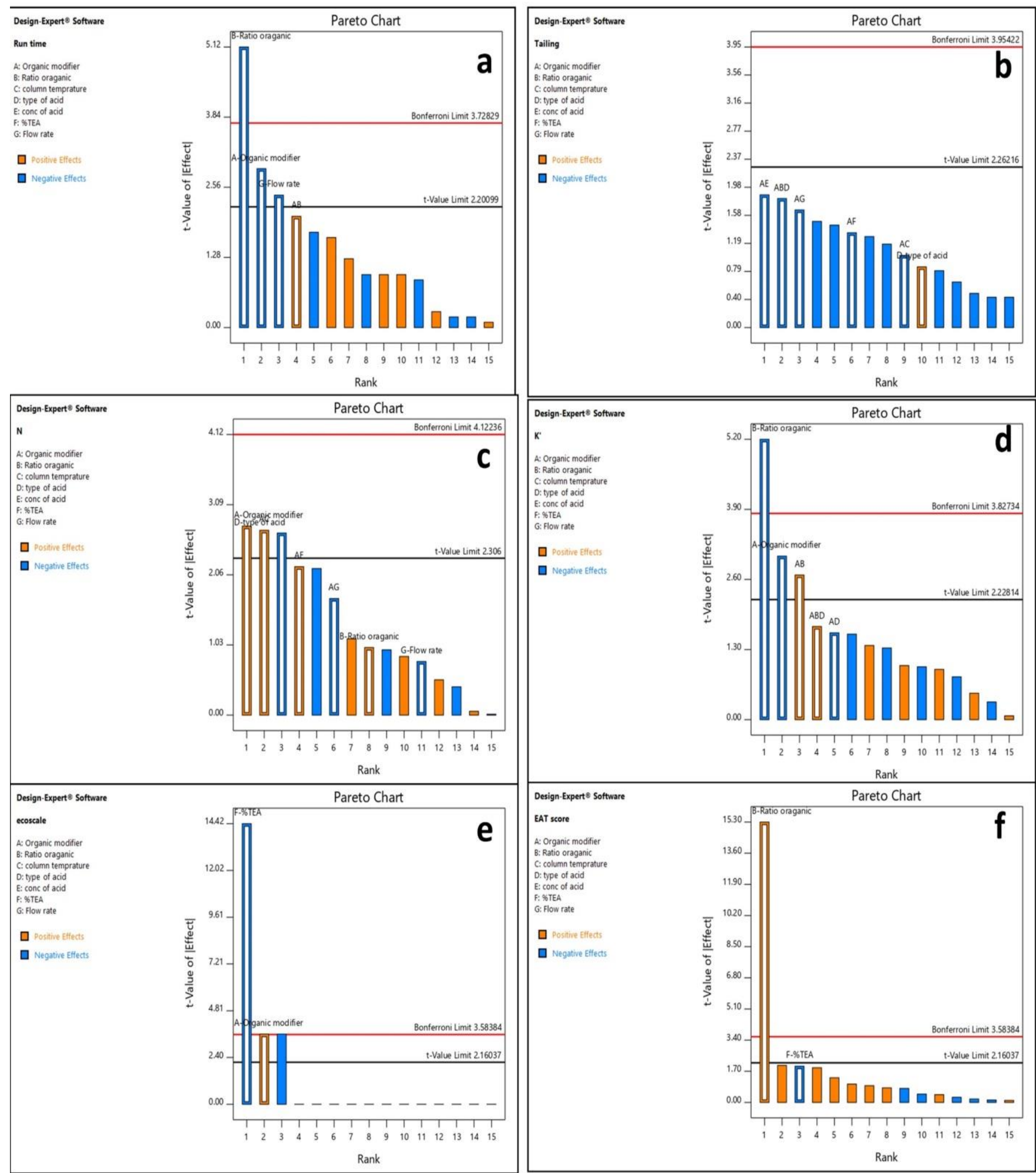

Figure 2. Pareto charts of the effects on the chromatographic responses: (a) run time, (b) tailing of FAV, (c) number of theoretical plates N, (d) capacity factor $\mathrm{k}^{\prime}$, (e) analytical eco-scale score, and (f) EAT score

solution was stable in a refrigerator at $4^{\circ} \mathrm{C}$ for two weeks (based on $98 \%$ recovery). Working standard solution was prepared by taking an aliquot of $50 \mu \mathrm{L}$ from the stock solution and diluting it to $25 \mathrm{~mL}$ with water in a calibrated $25-\mathrm{mL}$ volumetric flask. The concentration of this working solution was $800 \mathrm{ng} / \mathrm{mL}$.

\subsection{Construction of the calibration curve}

Into a set of $10-\mathrm{mL}$ volumetric flasks, aliquots of FAV working standard solution were quantitatively transferred and diluted to $10 \mathrm{~mL}$ with mobile phase and mixed thoroughly to yield final concentrations in the range of $20-240 \mathrm{ng} / \mathrm{mL}$. $20.0 \mu \mathrm{L}$ portions of each solution were injected in triplicates under the previously mentioned chromatographic conditions. 


\subsection{Analysis of laboratory prepared tablet}

The tablet of favipiravir is not available yet in the local market. So, a laboratory-prepared mixture imitating this tablet dosage form (Avigan ${ }^{\circledR} 200$ ) was prepared. The amounts of excipients were deduced from the handbook of pharmaceutical excipients [19]. The tablet was obtained by mixing $200 \mathrm{mg}$ FAV with the following excipients: $2.35 \mathrm{mg}$ colloidal silicon dioxide, $7.05 \mathrm{mg}$ povidone, $11.75 \mathrm{mg}$ low substituted hydroxypropyl cellulose, $11.75 \mathrm{mg}$ cross povidone, $10 \mathrm{mg}$ talc, $2.35 \mathrm{mg}$ sodium stearyl fumarate, and $5 \mathrm{mg}$ titanium dioxide. An accurately weighed amount of the laboratory synthetic tablet containing $10 \mathrm{mg}$ of FAV was moved into a calibrated $25-\mathrm{mL}$ volumetric flask and $10 \mathrm{~mL}$ distilled water was added, sonicated for $10 \mathrm{~min}$, and completed to the specified volume using distilled water. Then, the solution was filtered through a $0.45 \mu \mathrm{m}$ membrane nylon filter. The first portion of the filtrate was discarded and then $50 \mu \mathrm{L}$ of the filtrate was moved to a calibrated 25$\mathrm{mL}$ volumetric flask and completed to the mark with distilled water. Finally, $1 \mathrm{~mL}$ of this solution was moved to a $10-\mathrm{mL}$ volumetric flask and diluted to the specified volume with distilled water to procure a solution containing $80 \mathrm{ng} / \mathrm{mL}$. The same procedure was applied for another five portions of the synthetic tablets. The concentration of FAV in the tablet was determined by using the regression equation.

\subsection{Application to human plasma}

$100 \mu \mathrm{L}$ of plasma was transferred and spiked with FAV standard solutions $25-150 \mu \mathrm{g} / \mathrm{mL}$ so that FAV concentration in plasma lies within the range of 5-30 $\mu \mathrm{g} / \mathrm{mL}$. Then, $1 \mathrm{~mL}$ isopropanol was added to precipitate protein. Afterward, the mixtures were vortex-mixed for two minutes then centrifuged at $4000 \mathrm{rpm}$ for 10 minutes. Then the supernatant was transferred into a 5$\mathrm{ml}$ volumetric flask and completed to the mark with the mobile phase. For each mixture, an aliquot of $4 \mathrm{~mL}$ was transferred to a calibrated $10-\mathrm{mL}$ volumetric flask, and the mobile phase was added up to the mark to obtain final concentrations in the range of $40-240 \mathrm{ng} / \mathrm{mL} .20 .0$ $\mu \mathrm{L}$ portions of each solution were injected in triplicates under the previously mentioned chromatographic conditions. Blank experiments were made out by handling FAV free plasma samples in a similar way. The regression equation was derived.

$$
y=10.8387 x+120.9383
$$

where $\mathrm{y}$ and $\mathrm{x}$ represent mean peak area and FAV concentration $(\mathrm{ng} / \mathrm{mL})$, respectively.

\section{Results and Discussion}

\subsection{Method development and optimization}

The quality by Design approach was used throughout method development. First, the goal of the method (analytical target profile) is defined. The goal was the development of a fast green-sensitive HPLC method for the determination of FAV. Then, CQAs are outlined including short analysis time, good peak symmetry, increased number of theoretical plates, capacity factor $\mathrm{k}^{\prime}$, and greenness of the method. The greenness of the method was taken as a response to be optimized from the beginning to reach the optimum chromatographic conditions regarding analytical performance as well as greenness. After that, CMPs which could have a possible impact on CQAs are identified from preliminary experiments.

\subsubsection{Screening of parameters}

Preliminary experiments were first performed to find out the most suitable column and composition of the aqueous portion of the mobile phase. Different columns were tried including X-Bridge ${ }^{\mathrm{TM}}(150 \mathrm{~mm} \times 4.6 \mathrm{~mm}, 5$ $\mu \mathrm{m})$ column, Inertsil ODS-3 $(250 \mathrm{~mm} \times 4.6 \mathrm{~mm}, 5 \mu \mathrm{m})$ column, and Eclipse plus ${ }^{\circledR}$ C18 $(100 \mathrm{~mm} \times 4.6 \mathrm{~mm} \times 3.5$ $\mu \mathrm{m})$ column. The latter was found to be the best column regarding run time and peak shape. Different buffers were tried including phosphate and acetate buffers, but the peak was forked and not symmetric. When phosphoric acid and acetic acid were tried, the accepted peak was obtained. So, the type of acid used, and its concentration were further studied. A fractional factorial design was applied for the screening of parameters because it is the most suitable design for the evaluation of a large number of factors and detecting interaction between these factors. A regular (27-3) two-level fractional factorial design (Res IV) was selected for the screening of seven factors which are the type of acid, concentration of acid, organic modifier, the ratio of organic modifier, triethylamine concentration, column temperature, and flow rate. The low and high levels of each factor were determined. A set of 16 experiments were performed as shown in the design matrix in the supplementary material (Table S1). The responses obtained for CQAs (tailing of the peak, run time, number of theoretical plates $\mathrm{N}$, capacity factor $\mathrm{k}^{\prime}$, analytical ecoscale, and EAT score) were recorded. The greenness of the method was taken into account as one of the CQAs needs to be studied during the screening phase, in the form of analytical eco-scale and EAT score. Analytical eco-scale alone is not enough as an indication for the greenness because small changes in the volume used of organic solvents are not adequately reflected. So, EAT 
score was used along with eco-scale as responses reflecting method greenness.

\subsubsection{Fractional Factorial Design results}

Pareto charts were used to identify the most statistically significant factors that have an impact on different responses. Factors that exceed the t-limit line are significant. Pareto charts in Fig. 2 show that the ratio of organic modifiers has a statistically significant effect on run time, capacity factor, and EAT score while flow rate strongly affects run time. Isopropanol was found to be better than ethanol regarding run time and method greenness. Triethylamine has a negative effect on the eco-scale score while it does not significantly affect any other CQA, so it was excluded from the mobile phase to improve method greenness. Although column temperature was not found to be statistically significant for any CQA, the interaction between column temperature and organic modifier has a significant effect on the number of theoretical plates, so it was further studied and optimized. Based on the results of Pareto charts, three parameters that have the greatest significance were selected to be optimized including the ratio of organic modifier, flow rate, and column temperature. The other four factors were kept at the value that gives better chromatographic performance and greenness (organic modifier isopropanol, 0.1\% phosphoric acid, without triethylamine).

\subsubsection{Optimization using Box Behnken Design}

For optimization, the Box Behnken design was selected because it gives a quadratic model with a fewer number of experimental runs compared to Central Composite Design (CCD). A set of 15 experiments were carried out and responses were recorded as shown in the supplementary material (Table S2). For all experimental runs in Box Behnken optimization, the Analytical ecoscale is constant (equals 90) because isopropanol is the organic modifier in all experiments. So eco-scale was excluded from responses to be optimized because it does not change with small changes in the volume of organic solvent, unlike EAT score.

\subsubsection{Box Behnken design Results}

The design expert software analyzed the data and generated different plots that helped to understand the impact of different factors such as interaction plots, contour plots, and response surface plots. The threedimensional surface plots shown in Fig. 3 illustrate the effects of two factors on the response at a time. Optimum chromatographic conditions were reached using a desirability plot in the supplementary material (Fig. S1) which involves the use of $0.1 \%$ phosphoric acid solution and isopropanol in the ratio $98: 2 \% \mathrm{v} / \mathrm{v}$ as mobile phase at a flow rate of $0.80 \mathrm{~mL} / \mathrm{min}$ and column oven temperature of $35^{\circ} \mathrm{C}$. HPLC Chromatogram of $80 \mathrm{ng} / \mathrm{mL}$ of FAV under the optimum conditions is shown in Fig. 4. Results for system suitability tests of the proposed HPLC method are listed in the supplementary material (Table S3).

\subsubsection{Development of Design Space}

The design space in the QbD-approach describes the whole range of interactions between critical method parameters (CMPs) and their effects on CQAs that have been examined during the optimization process. This approach provides assurance on the quality of the developed method. Regions in which the specifications of a chromatographic response are not met are shaded out, leaving the yellow area which is a favorable region as shown in the supplementary material (Fig. S2). This means that in this design space, i.e., the yellow region, the method is robust and changes made in this region would not affect the quality of the proposed method.

\subsection{Method validation}

The method validation was carried out following the guidelines of ICH [20]. Limit of detection (LOD), the limit of quantitation (LOQ), linearity and range, accuracy, precision, and robustness were investigated.

\subsubsection{Linearity and range}

The linearity was confirmed by the construction of the calibration curves by plotting the mean peak area of FAV, on the y-axis, against the corresponding concentration of FAV in $\mathrm{ng} / \mathrm{mL}$, on the $\mathrm{x}$-axis. Statistical results were given in Table 1 .

Table 1. Linearity regression data for FAV in bulk using the proposed HPLC method.

\begin{tabular}{cc}
\hline Parameter & Value \\
\hline Linearity range $(\mathbf{n g} / \mathbf{m L})$ & $20-240$ \\
slope & 17.04 \\
SE of slope & 0.12 \\
Intercept & -34.04 \\
SE of Intercept & 16.63 \\
Correlation coefficient (r) & 0.9997 \\
SE of estimation & 26.05 \\
\hline
\end{tabular}

\subsection{2. $L O Q$ and $L O D$}

The guidelines of ICH (Q2 (R1)) were followed for the estimation of LOQ and LOD based on the standard deviation of the blank response and the slope of the calibration curve. The found values of LOD and LOQ were 2.01 and $6.11 \mathrm{ng} / \mathrm{mL}$ respectively. These values indicate the high sensitivity of the proposed chromatographic method. 

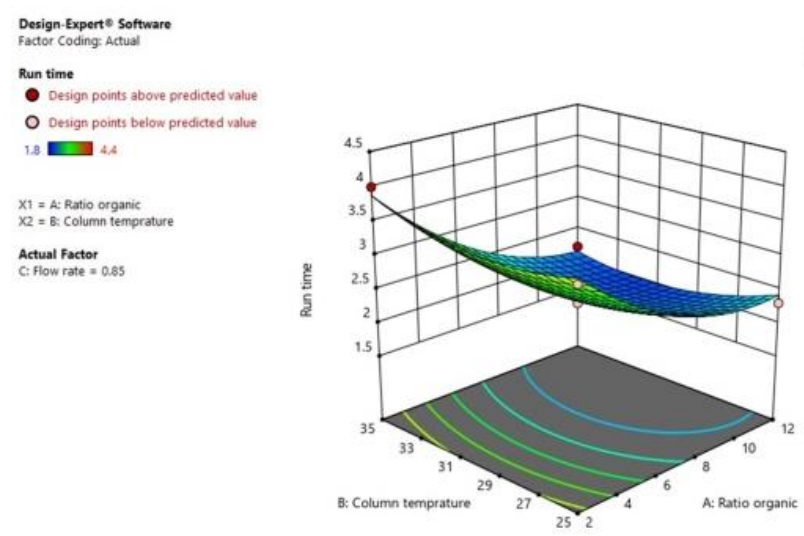

a

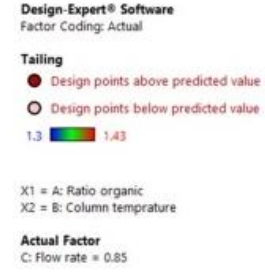

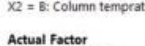

(a)

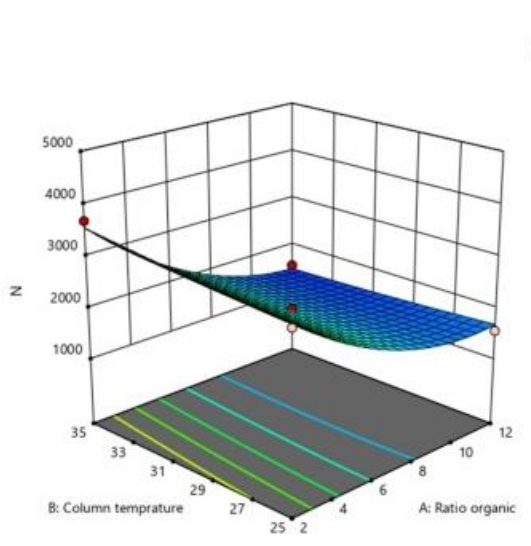

C

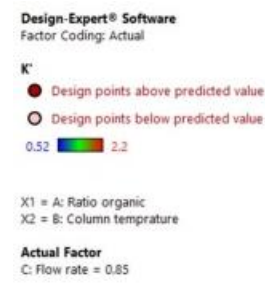

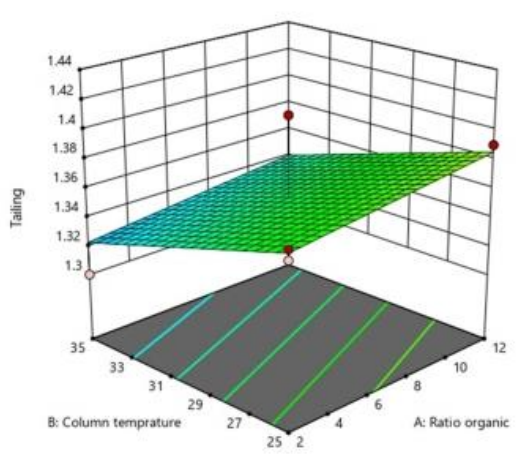

\begin{tabular}{|c|}
\hline $\begin{array}{l}\text { Design-Experte Software } \\
\text { Factor Coding: Actual }\end{array}$ \\
\hline $\mathrm{N}$ \\
\hline - Design points above predicted value \\
\hline O Design points below predicted value \\
\hline 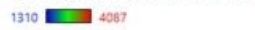 \\
\hline $\begin{array}{l}x_{1}=A \cdot \text { Ratio organic } \\
x_{2}=B_{2} \text { Column temprature }\end{array}$ \\
\hline $\begin{array}{l}\text { Actual factor } \\
\text { C. H flow rate }=0.85\end{array}$ \\
\hline
\end{tabular}

Design Experte Software
Fattor Coding Actual

EAT sore

- Design points above predited value O Design points below predicted value 0.1460 .61

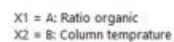
Actual Factor

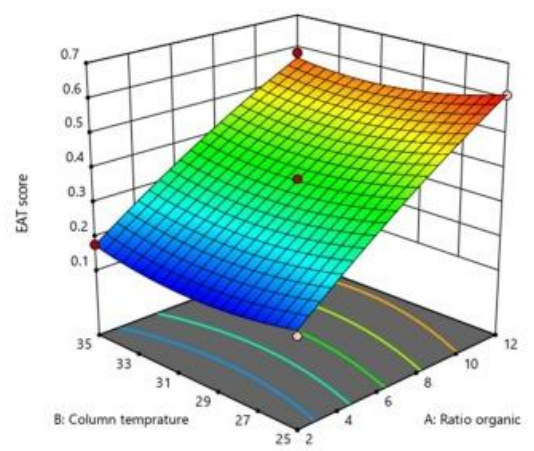

Figure 3. Response surface plots showing the impact of factors on the chromatographic responses: (a) run time, (b) tailing of FAV, (c) number of theoretical plates N, (d) capacity factor k', and (e) EAT score

FLD1 A, EX=361, Em=432 (TRAININGITRAINING 2020-09-30 12-39-131009-0801.D)

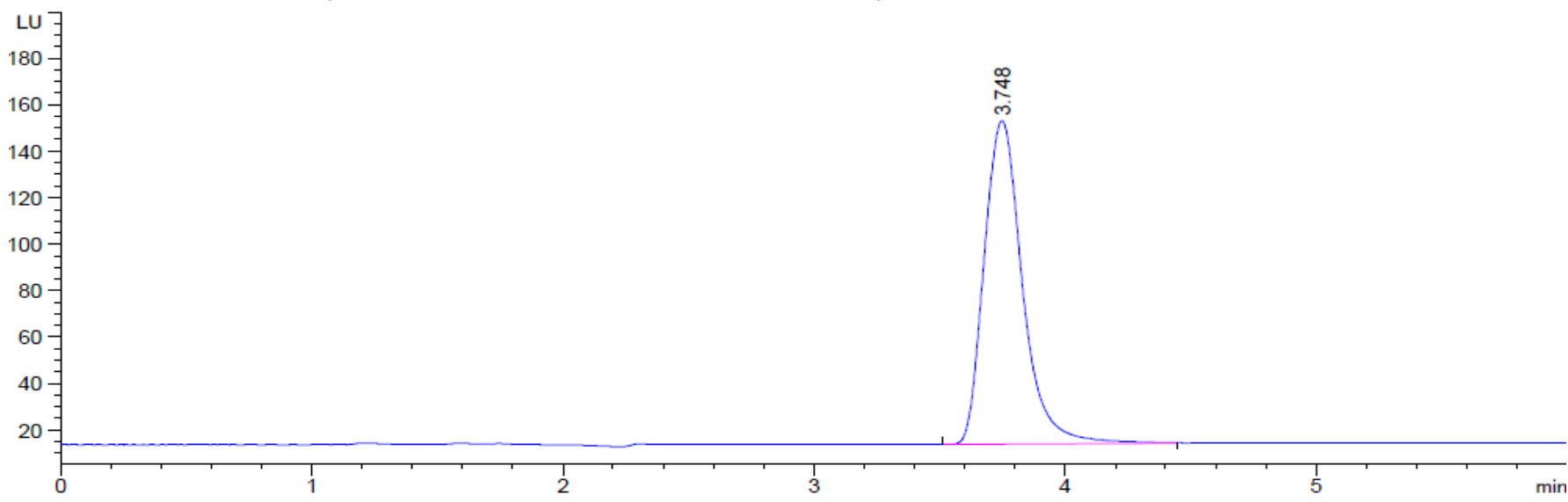

Figure 4. HPLC Chromatogram of $80 \mathrm{ng} / \mathrm{mL}$ of favipiravir (FAV) using a mixture of $0.1 \%$ phosphoric acid solution and isopropanol in the ratio $98: 2 \% \mathrm{v} / \mathrm{v}$ as mobile phase 
Table 2. Evaluation of accuracy for the determination of FAV using the proposed HPLC method

\begin{tabular}{ccccc}
\hline Drug & $\begin{array}{c}\text { Conc. } \\
\text { taken } \\
\text { (ng/mL) }\end{array}$ & $\begin{array}{c}\text { Conc. } \\
\text { found } \\
\text { (ng/mL) }\end{array}$ & \% Recovery & $\begin{array}{c}\text { Mean } \\
\text { \% recovery } \\
\mathbf{m} \text { SD }\end{array}$ \\
\hline \multirow{3}{*}{ FAV } & 60 & 59.92 & 99.86 & $99.42 \pm 0.59$ \\
& 80 & 79.00 & 98.75 & \\
\hline
\end{tabular}

* mean of three determinations.

\subsubsection{Accuracy and precision}

The accuracy of the proposed method was evaluated by performing the general analytical procedure for estimating three solutions containing different concentrations of FAV within the linearity range. The measurement was carried out in three replicates and the recovery percentage and standard deviation (SD) were determined. The $\%$ recovery values were close to $100 \%$ giving a sign for the respected degree of accuracy of the suggested method (Table 2). Triplicate samples corresponding to three different concentrations of FAV were assayed in one day and in three different successive days, respectively, to determine intra and inter-day precisions. The small values of $\%$ RSD were significant for the precision of the method (Table 3).

\subsubsection{Robustness}

The robustness of the current methodology was investigated by introducing small yet deliberate variations within its optimized parameters. The examined parameters in the robustness testing were the change in isopropanol ratio $(2 \% \pm 1)$, column temperature $\left(35^{\circ} \mathrm{C} \pm 2\right)$, and flow rate $(0.8 \mathrm{~mL} / \mathrm{min} \pm 0.1)$. The relative standard deviation was still less than $2 \%$ indicating the robustness of the method as shown in the supplementary material (Table S4).

Table 3. Application of the proposed HPLC method and comparison method [5] for the determination of the FAV in laboratory prepared tablet

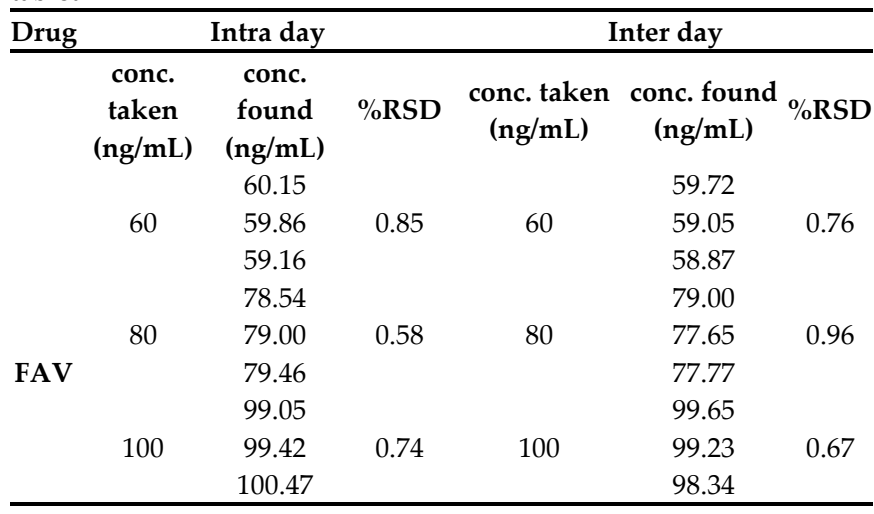

\subsection{Applications}

\subsubsection{Analysis of the pharmaceutical formulation}

The proposed method was applied for the analysis of FAV in its laboratory-prepared tablet with no interference from excipients. The percent recovery \pm S.D. was $98.97 \pm 0.76$ indicating the high accuracy and precision of the method. The chromatogram of FAV in the synthetic mixture is shown in the supplementary material (Fig. S3). The percent recovery values of the proposed method were compared with that of the reference method (5). There was no significant difference between the developed method and the comparison method as indicated by statistical analysis of the results using student's t-test and the F-test (Table 4).

Table 4. Application of the proposed HPLC method and comparison method [5] for the determination of the FAV in laboratory prepared tablet

\begin{tabular}{ccc}
\hline Sample No. & $\begin{array}{c}\text { Proposed method\% } \\
\text { Recovery of FAV }\end{array}$ & $\begin{array}{c}\text { Reported method } \% \\
\text { Recovery of FAV }\end{array}$ \\
\hline 1 & 99.62 & 98.25 \\
2 & 100.06 & 97.26 \\
3 & 98.60 & 99.45 \\
4 & 98.24 & 100.26 \\
5 & 99.36 & 101.02 \\
6 & 97.96 & 99.23 \\
\hline Mean \% recovery \pm & $98.97 \pm 0.76$ & $99.25 \pm 1.24$ \\
S.D. & 0.683 & $(2.228)^{*}$ \\
t-test & 2.647 & $(5.050)^{*}$ \\
F-test & * &
\end{tabular}

\subsubsection{Application in spiked human plasma}

Different studies were carried out to determine the pharmacokinetic effects of multiple doses of FAV. Cmax of FAV ranged from $22.01 \mu \mathrm{g} / \mathrm{mL}$ to $36.24 \mu \mathrm{g} / \mathrm{mL}$ in healthy American and Japanese subjects [21]. The proposed HPLC method was investigated for its capability to determine FAV in plasma samples through a linear range from 40 to $240 \mathrm{ng} / \mathrm{mL}$. Different solvents were tried to precipitate plasma proteins including methanol, ethanol, isopropanol, and acetonitrile. Isopropanol was selected as it gives the best percent extraction (91.54 \%) with a good peak shape. The plasma calibration curve was linear with the following equation: $y=10.8387 x+120.9383\left(r^{2}=0.9985\right)$. The method has been carried out on blank plasma in order to check the effect of the interfering matrix as shown in the supplementary material (Fig. S4).

Table 5. Application of the proposed chromatographic method to the determination of FAV in spiked human plasma

\begin{tabular}{cccc}
\hline $\begin{array}{c}\text { Conc. added } \\
(\mathrm{ng} / \mathrm{mL})\end{array}$ & $\begin{array}{c}\text { Mean conc. } \\
\text { found } \\
(\mathrm{ng} / \mathrm{mL})^{*}\end{array}$ & $\begin{array}{c}\text { Mean \% } \\
\text { recovery } \pm \mathrm{SD}\end{array}$ & \%RSD \\
\hline 40 & 38.24 & $95.59 \pm 4.23$ & 4.43 \\
\hline 80 & 78.17 & $97.71 \pm 1.99$ & 2.04 \\
\hline 120 & 123.12 & $102.60 \pm 2.54$ & 2.48 \\
\hline 160 & 163.38 & $102.12 \pm 2.11$ & 2.06 \\
\hline 240 & 237.09 & $98.79 \pm 3.45$ & 3.49 \\
\hline
\end{tabular}

The selectivity of the proposed method was proven by the determination of FAV in spiked human plasma samples without interference from the endogenous 
matrix. The results revealed the suitability of the method for the assay of FAV in spiked human plasma with acceptable recovery (Table 5).

\subsection{Assessment of the method greenness}

The greenness of the proposed chromatographic method was proved by calculating the analytical eco-scale and EAT scores. The calculated eco-scale was found to be 90 as shown in the supplementary material (Table S5). The proposed method was compared to the reported methods regarding sensitivity, greenness, and analysis time. Results shown in the supplementary material (Table S6) prove that the developed method is faster, greener, and more sensitive than the reported one.

\section{Conclusion}

The current study was carried out to develop a greensensitive chromatographic method with fluorescence detection for rapid quantitation of the new antiviral drug; favipiravir that has a potential therapeutic effect against the COVID-19 virus. The quality by Design approach was implemented throughout method development. The combination of $\mathrm{QbD}$ and green analytical chemistry results in the development of a design space that provides assurance of quality and improves method robustness. The adopted method is simple, fast, robust, and green and can replace the reported HPLC methods for the determination of favipiravir in routine analysis. Moreover, the high sensitivity of the proposed method allowed the determination of FAV in spiked human plasma.

\section{Acknowledgement}

We would like to acknowledge with much appreciation Dr. Mohammed Abdol Quader, R\&D section head in the pharmaceutical industry for his unlimited support and providing raw materials.

\section{References}

[1] A.A Elfiky, SARS-CoV-2 RNA dependent RNA polymerase (RdRp) targeting: an in silico perspective, J Biomol Struct Dyn, 39(9), 2020, 3204-3212.

[2] Y. Furuta, T. Komeno, T. Nakamura, Favipiravir (T-705), a broad spectrum inhibitor of viral RNA polymerase, Proc Jpn Acad Ser B Phys Biol Sci, 93(7), 2017, 449-463.

[3] M. Wang, R. Cao, L. Zhang, X. Yang, J. Liu, M. Xu, Z. Shi, Z. Hu, W. Zhong, G. Xiao, Remdesivir and chloroquine effectively inhibit the recently emerged novel coronavirus (2019-nCoV) in vitro, Cell Res, 30, 2020, 269-271.

[4] Q. Cai, M. Yang, D. Liu, J. Chen, D. Shu, J. Xia, X. Liao, Y. Gu, Q. Cai, Y. Yang, C. Shen, X. Li, L. Peng, D. Huang, J. Zhang, S. Zhang, F. Wang, J. Liu, L. Chen, S. Chen, Z. Wang, Z. Zhang, R. Cao, W. Zhong, Y. Liu, L. Liu, Experimental treatment with favipiravir for COVID-19: An open-label control study, Engineering, 6(10), 2020, 1192-1198.

[5] S. Joshi, J. Parkar, A. Ansari, A. Vora, D. Talwar, M. Tiwaskar, S. Patil, H. Barkate, Role of favipiravir in the treatment of COVID19, Int J Infect Dis, 102, 2021, 501-508.

[6] S. M.R. Hashemian, T. Farhadi, A.A. Velayati, A review on favipiravir: the properties, function, and usefulness to treat COVID-19, Expert Rev Anti-Infe, 19(8), 2021, 1029-1037.

[7] F. Guangling, D. Wenjuan, D. Yuxiao, Z. Renyong, G. Yanyan, D. Chonggang, S.A. Jinrui, A kind of favipiravir has the HPLC assay method of related substance, 2015, CN104914185B.

[8] İ. Bulduk, HPLC-UV method for quantification of favipiravir in pharmaceutical formulations, Acta Chromatogr, 33(3), 2021, 209215.

[9] S.M. Megahed, A.A. Habib, S.F. Hammad, A.H. Kamal, Experimental design approach for development of spectrofluorimetric method for determination of favipiravir; a potential therapeutic agent against COVID-19 virus: Application to spiked human plasma, Spectrochim Acta A, 249, 2021, 119241.

[10] A. Gałuszka, Z.M. Migaszewsk, P. Konieczka, J. Namieśnik, Analytical Eco-Scale for assessing the greenness of analytical procedures, Trac-Trend Anal Chem, 37, 2012, 61-72.

[11] Y. Gaber, U. Törnvall, M.A. Kumar, M.A. Amin, R. Hatti-Kaul, HPLC-EAT (Environmental Assessment Tool): A tool for profiling safety, health and environmental impacts of liquid chromatography methods, Green Chem, 13, 2011, 2021-2025.

[12] L.V. Candioti, M.M. De Zan, M.S. Cámara, H.C. Goicoechea, Experimental design and multiple response optimization. Using the desirability function in analytical methods development, Talanta, 124, 2014, 123-138.

[13] S. Orlandini, S. Pinzauti, S. Furlanetto, Application of quality by design to the development of analytical separation methods, Anal Bioanal Chem, 405, 2013, 443-50.

[14] A.A. Habib, M.M. Mabrouk, S.F. Hammad, S.M. Megahed, Implementation of factorial design for optimization of forced degradation conditions and development of validated stability indicating RP-HPLC method for Lidocaine hydrochloride, Der Pharma Chem, 7(6), 2015, 198-211

[15] A.A. Habib, S.F. Hammad, S.M. Megahed, A.H. Kamal, Innovative quality by design approach for development of green micellar HPLC method for simultaneous determination of atorvastatin and amlodipine, Chromatographia, 83, 2020, 12211231.

[16] C. Ye, J. Liu, F. Ren, N. Okafo, Design of experiment and data analysis by JMP® (SAS institute) in analytical method validation, J Pharm Biomed Anal, 23, 2000, 581-589.

[17] S.M. Megahed, A.A. Habib, M.M. Mabrouk, S.F. Hammad, Application of chromatographic response function in development of stability indicating HPLC method for determination of benoxinate hydrochloride and fluorescein sodium mixture using factorial design, J Adv Med Pharm Res, 1, 2020, 1-8.

[18] S.L.C. Ferreira, R.E. Bruns, H.S. Ferreira, G.D. Matos, J.M. David, G.C. Brandão, E.G.P. da Silva, L.A. Portugal, P.S. dos Reis, A.S. Souza, W.N.L. dos Santos, Box-Behnken design: An alternative for the optimization of analytical methods, Anal Chim Acta, 597, 2007, 179-186.

[19] R.C. Rowe, P.J. Sheskey, M.E. Quinn, Handbook of Pharmaceutical Excipients (6. edition), 2009, UK, Pharmaceutical Press.

[20] C. Nehls, M. Buonarati, S. Cape, R. Islam, C. Satterwhite, C. Briscoe, R. Hayes, A. Dinan, K. Sales, S. Anderson, J. Vance, J. Lindsay, J. Zimmer, P. Couerbe, A. Khadang, S. Maasjo, O. Bravo, K. Lindley, L. Moran, T. Sangster, J. Vija, J. Stamatopoulos, J. Lin, S. Reuschel, A. Underberg, R. MacNeill, L. Matassa, A. Spytko, W. Garofolo, N. Savoie, P. Rhyne, J. Ambrosius, V. Barra, D. Dufield, M. Luna, F. Spriggs, E. Fedorov, H. Ritzén, S. Fatmi, C. Kane, M. Bouhajib, C. DiMarco, A. 
Iordachescu, A. Tudoroniu, E. Farley, B. Stouffer, E. Tabler, S. McCown, J. Bower, T. Harrison, S. Karnik, M. Brown, P. Joyce, I. DuBey, B. Hoffpauir, N. Boudreau, J. Bergeron, H. Wang, H. Feng, S. Zhou, E. Wells, J. Pirro, X. Fang, J. Shi, C. Yang. GCC Consolidated Feedback to ICH on the 2019 ICH M10 Bioanalytical Method Validation Draft Guideline, Bioanalysis, 11(18s), 2019, 1-228.

[21] Pharmaceuticals and Medical Devices Agency: Avigan (favipiravir) Review Report, 2014, https://www.pmda.go.jp/files/000210319.pdf. 


\section{Suplementary materials}

Table S1. Fractional factorial design matrix for the effect of different CMPs on CQAs

\begin{tabular}{|c|c|c|c|c|c|c|c|c|c|c|c|c|c|}
\hline Run & $\begin{array}{c}\text { A:Organic } \\
\text { modifier }\end{array}$ & $\begin{array}{c}\text { B:Organic } \\
\text { ratio }\end{array}$ & $\begin{array}{l}\text { C:column } \\
\text { temprature }\end{array}$ & $\begin{array}{c}\text { D:type of } \\
\text { acid }\end{array}$ & $\begin{array}{c}\text { E:conc of } \\
\text { acid }\end{array}$ & $\mathrm{F}: \% \mathrm{TEA}$ & $\begin{array}{l}\text { G:Flow } \\
\text { rate }\end{array}$ & $\begin{array}{l}\text { Run } \\
\text { time }\end{array}$ & Tailing & $\mathbf{N}$ & $\mathbf{k}^{\prime}$ & ecoscale & $\begin{array}{l}\text { EAT } \\
\text { score }\end{array}$ \\
\hline 1 & $\mathrm{EtOH}$ & 5 & 40 & $\begin{array}{c}\text { phosphoric } \\
\text { acid }\end{array}$ & 0.1 & 0.01 & 1 & 2.3 & 1.34 & 1853 & 0.96 & 80 & 0.231 \\
\hline 2 & IPA & 5 & 40 & $\begin{array}{c}\text { phosphoric } \\
\text { acid }\end{array}$ & 0.01 & 0.01 & 0.7 & 1.8 & 1.33 & 2117 & 0.45 & 82 & 0.164 \\
\hline 3 & $\mathrm{EtOH}$ & 25 & 40 & $\begin{array}{c}\text { phosphoric } \\
\text { acid }\end{array}$ & 0.01 & 0 & 1 & 1.2 & 1.26 & 1644 & 0.28 & 88 & 0.604 \\
\hline 4 & IPA & 5 & 40 & acetic acid & 0.01 & 0 & 1 & 1.4 & 1.42 & 1823 & 0.21 & 88 & 0.182 \\
\hline 5 & IPA & 5 & 25 & $\begin{array}{c}\text { phosphoric } \\
\text { acid }\end{array}$ & 0.1 & 0 & 1 & 2.5 & 1.25 & 2082 & 1.16 & 90 & 0.325 \\
\hline 6 & $\mathrm{EtOH}$ & 25 & 25 & acetic acid & 0.1 & 0 & 1 & 1.2 & 1.42 & 1498 & 0.26 & 86 & 0.604 \\
\hline 7 & IPA & 25 & 40 & acetic acid & 0.1 & 0.01 & 1 & 1 & 0.97 & 2053 & 0.18 & 80 & 0.65 \\
\hline 8 & $\mathrm{EtOH}$ & 25 & 25 & $\begin{array}{c}\text { phosphoric } \\
\text { acid }\end{array}$ & 0.1 & 0.01 & 0.7 & 1.6 & 1.33 & 1920 & 0.32 & 80 & 0.563 \\
\hline 9 & IPA & 25 & 25 & $\begin{array}{c}\text { phosphoric } \\
\text { acid }\end{array}$ & 0.01 & 0.01 & 1 & 0.9 & 1.34 & 1489 & 0.24 & 82 & 0.585 \\
\hline 10 & IPA & 25 & 25 & acetic acid & 0.01 & 0 & 0.7 & 1.3 & 1.45 & 1743 & 0.26 & 88 & 0.591 \\
\hline 11 & $\mathrm{EtOH}$ & 5 & 25 & acetic acid & 0.01 & 0.01 & 1 & 2.4 & 1.35 & 1722 & 1 & 78 & 0.241 \\
\hline 12 & IPA & 5 & 25 & acetic acid & 0.1 & 0.01 & 0.7 & 2.1 & 1.44 & 1764 & 0.2 & 80 & 0.191 \\
\hline 13 & $\mathrm{EtOH}$ & 5 & 25 & $\begin{array}{c}\text { phosphoric } \\
\text { acid }\end{array}$ & 0.01 & 0 & 0.7 & 3.6 & 1.27 & 1896 & 1.16 & 88 & 0.254 \\
\hline 14 & $\mathrm{EtOH}$ & 5 & 40 & acetic acid & 0.1 & 0 & 0.7 & 4.6 & 1.29 & 766 & 1.35 & 86 & 0.324 \\
\hline 15 & IPA & 25 & 40 & $\begin{array}{c}\text { phosphoric } \\
\text { acid }\end{array}$ & 0.1 & 0 & 0.7 & 1.4 & 1.29 & 3538 & 0.26 & 90 & 0.637 \\
\hline 16 & EtOH & 25 & 40 & acetic acid & 0.01 & 0.01 & 0.7 & 1.5 & 1.39 & 1501 & 0.23 & 78 & 0.528 \\
\hline
\end{tabular}

TEA: Triethylamine, EtOH: ethanol, IPA: isopropyl alcohol, N: number of theoretical plates, $\mathrm{k}^{\prime}$ : capacity factor

Table S2. Box Behnken design matrix for the effect of different CMPs on CQAs

\begin{tabular}{|c|c|c|c|c|c|c|c|c|}
\hline & Factor 1 & Factor 2 & Factor 3 & Response 1 & Response 2 & Response 3 & Response 4 & Response 5 \\
\hline Run & A:Ratio organic & B:Column temprature & C:Flow rate & Run time & Tailing & N & K' & EAT score \\
\hline $\mathbf{1}$ & 7 & 30 & 0.85 & 2.4 & 1.41 & 1940 & 0.81 & 0.371 \\
\hline $\mathbf{2}$ & 7 & 35 & 1 & 2.2 & 1.31 & 1622 & 0.73 & 0.4 \\
\hline $\mathbf{3}$ & 12 & 35 & 0.85 & 2.2 & 1.32 & 1548 & 0.56 & 0.583 \\
\hline $\mathbf{4}$ & 12 & 30 & 0.7 & 2.5 & 1.43 & 1908 & 0.63 & 0.546 \\
\hline $\mathbf{5}$ & 7 & 25 & 1 & 2.5 & 1.31 & 1754 & 0.75 & 0.455 \\
\hline $\mathbf{6}$ & 2 & 30 & 0.7 & 4.4 & 1.37 & 4087 & 2.2 & 0.16 \\
\hline $\mathbf{7}$ & 2 & 30 & 0.85 & 3.6 & 1.37 & 3091 & 1.46 & 0.159 \\
\hline $\mathbf{8}$ & 2 & 25 & 0.85 & 4 & 1.3 & 3694 & 2.15 & 0.177 \\
\hline $\mathbf{9}$ & 2 & 35 & 0.85 & 2.3 & 1.39 & 1556 & 0.52 & 0.61 \\
\hline $\mathbf{1 0}$ & 12 & 25 & 0.7 & 3.2 & 1.38 & 2374 & 0.89 & 0.407 \\
\hline $\mathbf{1 1}$ & 7 & 25 & 0.7 & 3 & 1.34 & 2303 & 0.84 & 0.382 \\
\hline $\mathbf{1 2}$ & 7 & 35 & 1 & 1.8 & 1.35 & 1310 & 0.66 & 0.561 \\
\hline $\mathbf{1 3}$ & 12 & 30 & 0.85 & 2.4 & 1.31 & 1994 & 0.82 & 0.371 \\
\hline $\mathbf{1 4}$ & 7 & 30 & 2.3 & 1.34 & 1962 & 0.83 & 0.356 \\
\hline $\mathbf{1 5}$ & 7 & 30 & & & & & & 0.3 \\
\hline
\end{tabular}

Table S3. Results of system suitability tests for the proposed HPLC method

\begin{tabular}{|l|l|}
\hline Parameter & FAV \\
\hline Retention time $\left(\mathrm{R}_{\mathrm{T}}\right)(\mathrm{min})$ & 3.75 \\
\hline Capacity factor $\left(\mathrm{k}^{\prime}\right)$ & 2.39 \\
\hline Theoretical plates $(\mathrm{N})$ & 3818 \\
\hline
\end{tabular}

3818

Asymmetry factor 
Design-Expert ${ }^{\circledR}$ Software

Factor Coding: Actual

\section{All Responses}

\section{Actual Factors}

A: Ratio organic $=2$

B: Column temprature $=35$

C: Flow rate $=0.805356$

\section{Responses}

Desirability $=0.789057$

Run time $=4.1$

Tailing $=1.32907$

$\mathrm{N}=3766.34$

$\mathrm{K}^{\prime}=2.1263$

EAT score $=0.17773$

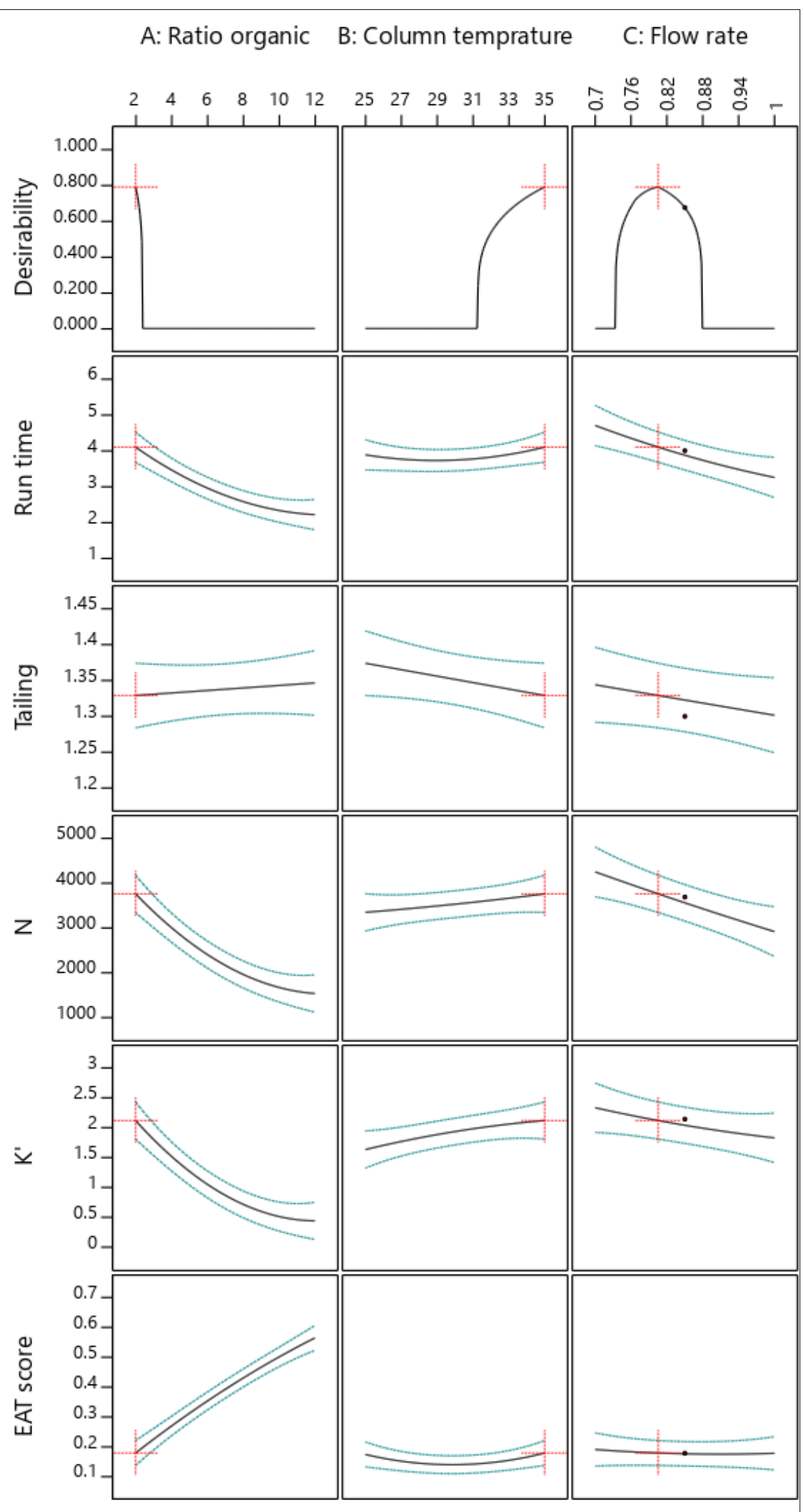

Figure S1. Desirability plot showing optimum chromatographic conditions 
Design-Expert Software Factor Coding: Actual

Overlay Plot

Run time

Tailing

N

EAT score

X1 $=$ A: Ratio organic

$X_{2}=\mathrm{B}$ : Column temprature

\section{Actual Factor}

C: Flow rate $=0.805356$

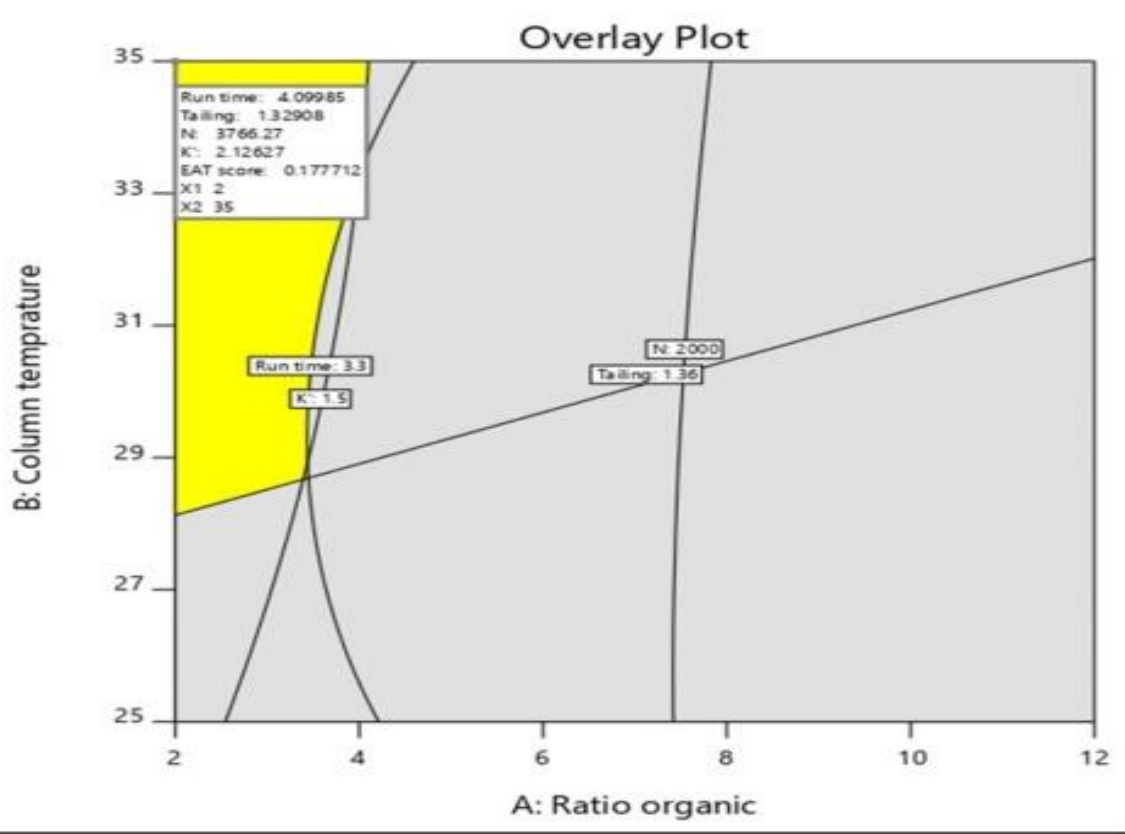

Design-Expert Software Factor Coding: Actual

Overlay Plot

Run time

Tailing

N

EAT score

Design Points

$\mathrm{X}_{1}=\mathrm{A}$ : Ratio organic

$X_{2}=C$ : Flow rate

Actual Factor

B: Column temprature $=35$

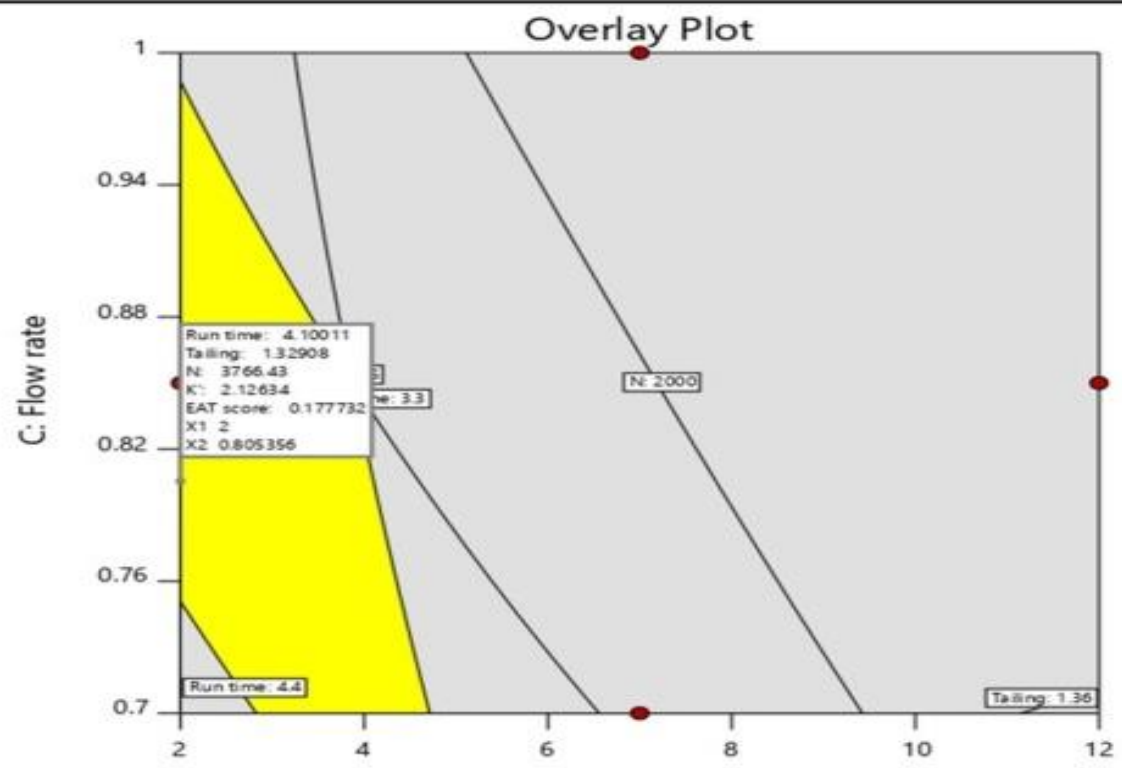

A: Ratio organic

Design-Expert Software Factor Coding: Actual

\section{Overlay Plot}

Run time

$\mathrm{N}$

EAT score

Design Points

X1 = B: Column temprature

$\mathrm{X}_{2}=\mathrm{C}$ : Flow rate

\section{Actual Factor}

A: Ratio organic $=2$

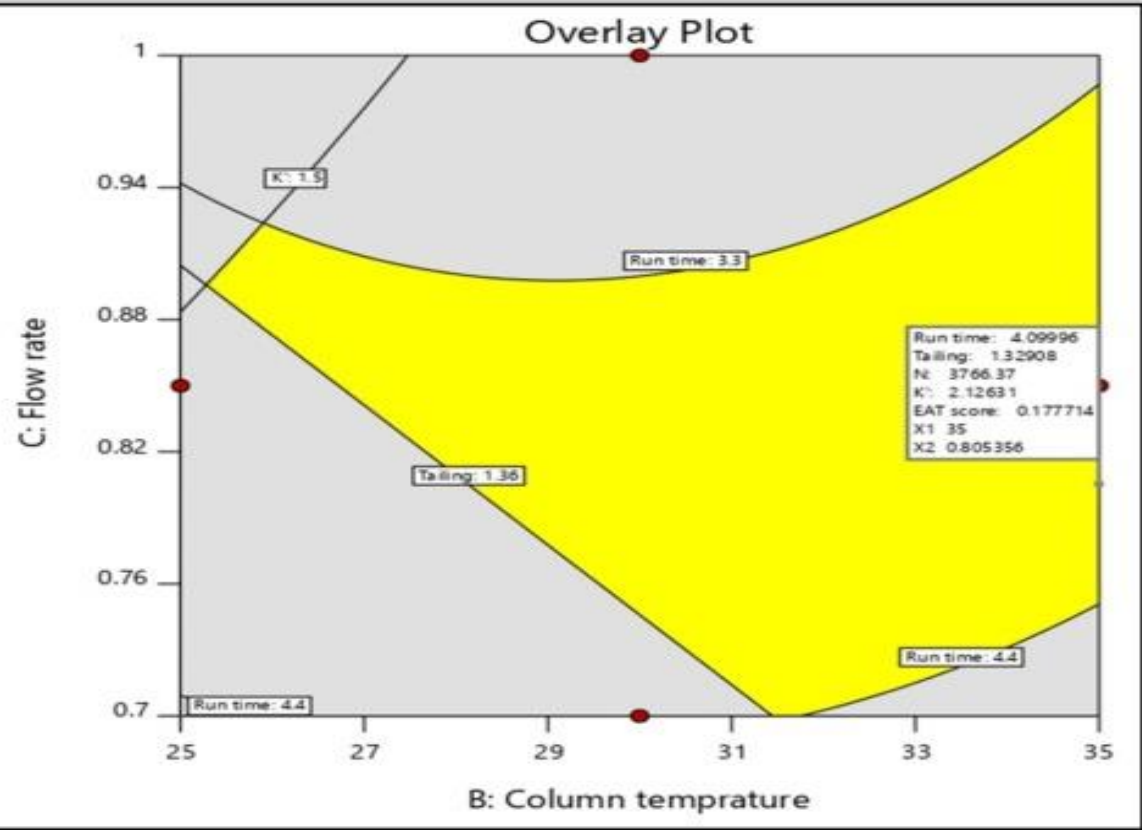

Figure S2. Design space (overlay plot) for different chromatographic conditions 
Table S4. Robustness results for the proposed HPLC method

\begin{tabular}{|c|c|c|c|c|c|}
\hline \multirow{2}{*}{\multicolumn{2}{|c|}{ Parameters }} & \multicolumn{4}{|c|}{ FAV } \\
\hline & & Recovery \% & Mean recovery \% & S.D & R.S.D \\
\hline \multirow{3}{*}{ Ratio of isopropanol (\%) } & 1 & 97.72 & \multirow{3}{*}{98.72} & \multirow{3}{*}{0.80} & \multirow{3}{*}{0.81} \\
\hline & 2 & 98.75 & & & \\
\hline & 3 & 99.69 & & & \\
\hline \multirow{3}{*}{ Flow rate $(\mathrm{mL} / \mathrm{min})$} & 0.7 & 98.52 & \multirow{3}{*}{98.92} & \multirow{3}{*}{0.41} & \multirow{3}{*}{0.41} \\
\hline & 0.8 & 98.75 & & & \\
\hline & 0.9 & 99.48 & & & \\
\hline \multirow{3}{*}{ Column temperature $\left({ }^{\circ} \mathrm{C}\right)$} & 33 & 100.13 & \multirow{3}{*}{99.16} & \multirow{3}{*}{0.69} & \multirow{3}{*}{0.69} \\
\hline & 35 & 98.75 & & & \\
\hline & 37 & 98.59 & & & \\
\hline
\end{tabular}

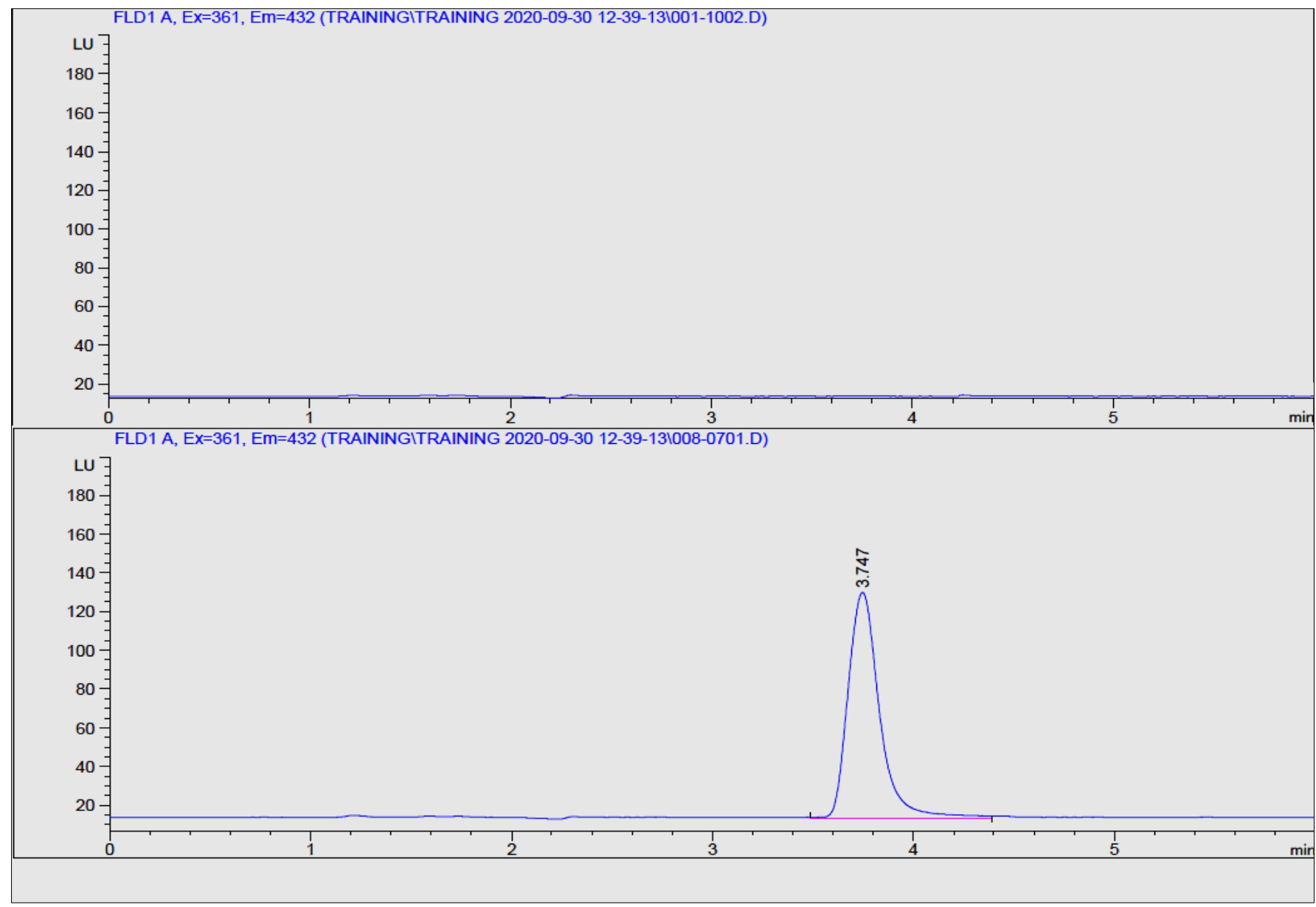

Figure S3. Chromatograms of (a) blank experiment containing all possible excipients, and (b) laboratory prepared mixture containing $80 \mathrm{ng} / \mathrm{mL}$ FAV using the proposed HPLC method 


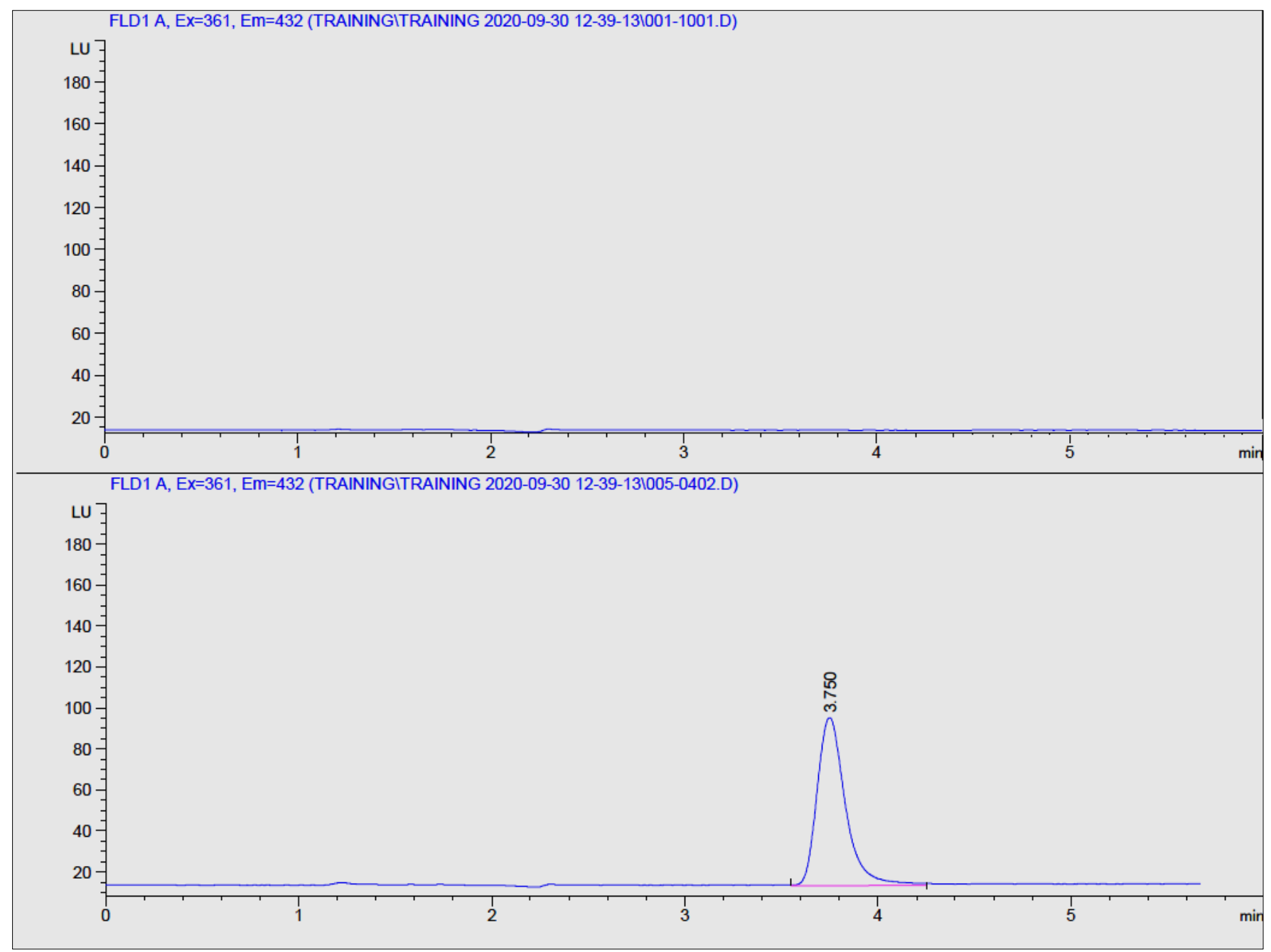

Figure S4. Chromatograms of (a) blank plasma sample, and (b) plasma sample containing $80 \mathrm{ng} / \mathrm{mL}$ FAV using the proposed HPLC method

Table S5. Calculation of analytical eco-scale for the developed method

\begin{tabular}{|c|c|}
\hline Reagents/Instruments & Penalty points \\
\hline \multicolumn{2}{|c|}{ Reagents } \\
\hline Phosphoric acid & 2 \\
\hline isopropanol & 4 \\
\hline \multicolumn{2}{|c|}{ Instruments } \\
\hline HPLC & 1 \\
\hline Occupational hazards & 0 \\
\hline Waste & 3 \\
\hline Total penalty points & $\sum 10$ \\
\hline Analytical eco-scale score & 90 \\
\hline
\end{tabular}

Table S6. Comparison of the proposed HPLC method with the reported one

\begin{tabular}{|l|c|c|c|}
\hline & Reported method [5] & Reported method [6] & Proposed method \\
\hline Linearity range & $2-8 \mu \mathrm{g} / \mathrm{mL}$ & $10-100 \mu \mathrm{g} / \mathrm{mL}$ & $40-240 \mathrm{ng} / \mathrm{mL}$ \\
\hline Limit of detection (LOD) & $\mathrm{NA}$ & $1.20 \mu \mathrm{g} / \mathrm{mL}$ & 2.00 \\
\hline Limit of Quantitation (LOQ) & $\mathrm{NA}$ & $3.60 \mu \mathrm{g} / \mathrm{mL}$ & 6.11 \\
\hline Analysis time (min) & 11.0 & 15.0 & 4.5 \\
\hline Analytical eco-scale score & 83 & 83 & 90 \\
\hline HPLC-EAT score & 3.934 & 5.364 & 0.187 \\
\hline
\end{tabular}

